\title{
СТРУКТУРНИ И КУЛТУРОЛОШКИ АСПЕКТИ НА ОДГОВОРИТЕ НА КОМПЛИМЕНТИТЕ ВО МАКЕДОНСКИОТ И ВО АЛБАНСКИОТ ЈАЗИК ВО СПОРЕДБА СО АНГЛИСКИОТ
}

\author{
Нита Деари \\ ООУ „Фаик Коница“, Слупчане \\ nita_selimi@yahoo.com
}

Во овој труд се истражуваат комплиментите и нивните одговори за да се видат културолошките разлики и сличности меѓу македонскиот, албанскиот и англискиот народ при употреба на овој говорен чин. Истражувањето се базира на два корпуса: првиот од реални ситуации (КРС) кој содржи 100 примери и вториот преку прашалник со ситуации (КПС) кој содржи 1320 примери, коишто ни овозможуваат да дојдеме до важни сознанија. Се истражува втората секвенца на говорниот чин на давање комплименти, т.е. одговорите на комплиментите за да се види до која мера тие ја отсликуваат културата на македонскиот и на албанскиот народ. Посебно внимание се обрнува и на теоријата на учтивост на Браун и Левинсон и поимот лице, во чии рамки се истражуваат одговорите на комплиментите за да се види како се перципира учтивоста во овие две култури и дали се склони кон самопофалба или кон скромност. Одговорите на комплиментите се истражуваат и како потенцијални чинови кои го загрозуваат лицето или како чинови кои ги ублажуваат заканите за лицето. Преку анализа на одговорите на комплиментите, според варијаблите етникум, пол и возраст, се проверува колку овие три параметри влијаат врз начинот на кој се одговара на комплимент и дали има претпочитани модели на одговори за овие категории. Сознанијата се поврзани со хипотезата дека постојат сличности меѓу македонската и албанската култура како последица на нивната припадност во една заедничка култура-балканската.

Клучни зборови: говорни чинови, теорија на учтивост, лице, чинови кои го загрозуваат лицето, комплименти,одговори на комплименти 


\title{
STRUCTURAL AND CULTURAL ASPECTS OF COMPLIMENT RESPONSES IN MACEDONIAN AND ALBANIAN IN COMPARISON TO ENGLISH
}

\author{
Nita Deari \\ Faik Konica Elementary School, Slupčane \\ nita_selimi@yahoo.com
}

This paper investigates compliments and compliment responses in order to reveal cultural differences and similarities between Macedonian, Albanian and English language through the use of this speech act. The main hypothesis is that there are similarities between Macedonian and Albanian culture as they belong to a broader cultural milieu of the Balkans. The research is based on two corpora: the first corpus consists of everyday life situations (CELS or KRS) and it contains 100 compliment exchanges and the second corpus is created through a Discourse Completion Test (CDCT or KPS) and it contains 1320 examples. Compliment responses are examined with the aim to see how much they reflect the cultural background of Macedonian and Albanian nation. A particular attention is paid to Brown and Levinson's Politeness theory and to the notion of Face in the frames of which compliment responses are examined with the aim to learn how these two cultures perceive politeness and whether they are more prone to self-praise or modesty. Compliment responses are also examined as potential Face-threatening or Face-saving acts. Nationality, sex and age of the respondents are taken into consideration as factors that influence compliment responses.

Keywords: speech acts, politeness theory, face, face-threatening acts, compliments, compliment responses 


\section{1 Вовед}

Целта на ова истражување лежи во пронаоѓањето на културолошките норми кои влијаат врз одговарањето на комплиментите во три различни култури (македонската, албанската и англиската култура). Сакаме да откриеме како се одговара на комплимент и дали се претпочитаат некои етнички модели со кои се рефлектира културата на говорителите на тој јазик и да се види дали има сличности помеѓу албанската и македонската култура во користењето на овој чин и да се направи нивна споредба со англискиот.

Во англискиот јазик истражувањата во ова поле се доста обемни. Исто така, има голем број истражувања во полето на меѓукултурната прагматика од странски автори кои го споредуваат говорниот чин на давање и одговор на комплименти во својот јазик со англискиот (Chiang and Pochtrager 1993, Lorenzo-Dus 2001, Behnam and Aamizadeh 2007, Bergqvist 2009 и др.). Меѓу најистакнатите автори кои се занимавале со овој говорен чин се Холмс (Holmes 1986, 1988, 1995), Волфсон (Wolfson 1983), Мејнс (Manes 1983), Померанц (Pomerantz 1978), Херберт (Herbert 1989), Нап (Knapp 1984), и др. Според Херберт (Herbert 1990: 202), овој чин како целина служи за преговарање солидарност, а Мејнс и Волфсон (Manes and Wolfson 1981: 116) даваат една многу општа дефиниција на комплиментите како изрази на позитивно вреднување.

Одговорите на комплиментите, од друга страна, се опишуваат како разрешување на притисокот од конфликтен разговор (Pomerantz 1978). Херберт (Herbert 1989) пак, ги дефинира како „сѐ што следи по еден определен комплимент“.

Фокусот на истражувањето се одговорите на комплиментите кои се класифицираат и се анализираат врз основа на три независни категории (варијабли): полот, етникумот и возраста на учесниците во овој говорен чин.

За да се добие појасна слика за тоа како гледаат на пофалбата припадниците на македонската и на албанската култура, одговорите на комплиментите се анализираат и според теоријата на учтивост на Браун и Левинсон (Brown and Levinson 1987), поконкретно во рамките на негативната и позитивната учтивост. Се обрнува внимание и на поимот лище (face), за да се види дали при давање или одговарање на комплименти се води сметка за неговото одржување. Според Браун и Левинсон лицето е нешто во што емоционално се инвестира, а што може да се изгуби, одржи или да се засили (Brown and Levinson 1987: 61) и затоа при комуникација треба да се биде внимателен да 
не му се наштети на лицето на другиот. Комплиментите ќе се анализираат и како говорни чинови кои го загрозуваат лицето (Face-threatening acts), па треба да се види дали во албанската и во македонската култура се сметаат како чинови кои го загрозуваат позитивното или негативното лице на соговорниците.

Главната претпоставка во овој труд е дека постојат сличности во изборот на стратегиите на одговарање на комплименти во македонската и во албанската култура бидејќи и двете припаѓаат во една заедничка култура - балканската.

Исто така, се претпоставува дека овие две култури се разликуваат од англиската во начинот на одговарање на комплиментите.

Третата претпоставка е дека, сепак, постојат извесни разлики меѓу двете балкански култури: албанската и македонската, но тие разлики треба да ги утврдиме.

Поради широката опфатност на три различни култури и поради потребата да се држиме до одреден обем на трудот и да извршиме подлабока анализа на гореспомнатите независни варијабли, овој труд има и објективни ограничувања.

Така, трудот не ги опфаќа комплиментите и нивните одговори меѓу соговорници од различна етничка припадност, туку само соговорници од иста националност поради тоа што би се анализирале само комплименти и одговори на македонски јазик, т.е. како даваат и одговараат на комплименти само учесниците на кои македонскиот јазик им е немајчин (во овој случај Албанци), поради тешкотијата да се пронајдат комплименти и одговори на комплименти на албански јазик од говорители од друга етничка припадност.

Истражувањето нема да го обработува ни параметарот општествена блискост меѓу соговорниците, иако од истражувањата (Holmes 1995: 120121, Terkourafi 2004: 132) се забележува дека општественото растојание влијае врз изборот на стратегијата за одговарање на комплименти или толкувањето на комплиментите, воопшто.

Во трудот не се земени предвид присутноста, односно неприсутноста на други лица при давање на комплиментот, а која се претпоставува дека ќе влијае врз одговорите на комплименти, особено на тие што се сметаат за непристојни или пак интимни (Davis 2008).

Последниот фактор, кој не е опфатен во истражувањето, е општествениот статус на учесниците во говорниот чин на давање и одговарање на комплименти, кој според досегашните истражувања влијае и на количината на размена на комплименти (Holmes 1988: 457).

Нашата анализа на говорниот чин на одговарање на комплименти се

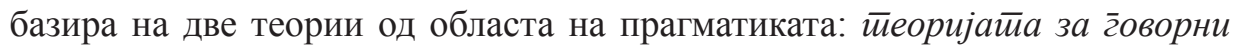

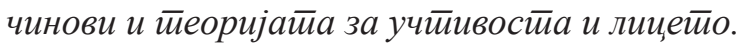


Теоријата за говорните чинови опишува што извршуваат исказите во одредена функција. Оваа теорија ја започнува Џон Остин со неговиот труд How to do things with words (Austin 1962). Џон Серл ја развива уште повеќе и ги дефинира говорните чинови како основни или минимални единици на јазичната комуникација (Searle 1969). Со други зборови, може да се каже дека говорните чинови претставуваат дејства кои се вршат со самото искажување на еден исказ, и секоја вербална комуникација, било да е пишана или усна, претставува говорен чин.

Во однос на теоријата на учтивост, Ирвинг Гофман, како првиот што се занимава со неа, го воведува терминот лище (face) и рабойа на лищейо (face-work). Преку терминот лице, Гофман (Goffman 1967: 5) ги означува оние позитивни општествени вредности кои поединецот ги стекнал за време на одредени контакти. Лицето претставува слика за сопствената личност создадена во рамки на прифатени општествени особини и тоа е во тесна врска со чувствата на поединецот. Со терминот рабойа на лицейо (face-work) Гофман (1967: 12) ги означува дејствата на поединецот кои се конзистентни со неговото лице и служат за неутрализирање на оние чинови кои г̄о загррозуваай лищейо (Face-threatening acts, понатаму ЧЗЛ).

Во македонскиот јазик освен терминот лице, поимот face може да означи и образ. Кусевска (2012: 23) во своето истражување, истакнува дека иако овие два збора се слични и во одредени околности може да се заменат меѓусебно, разликата се состои во тоа што терминот лице повеќе се користи за да се опише карактерот на индивидуата (пр. Си г̄o йокажа висииинскойо лице!), додека терминот образ за моралната страна на поединецот (пр. Сакам gа умрам со чисти образ).

И во албанскиот јазик, слично со македонскиот, се користат термините fytyrë и faqe, кои ја означуваат карактерната и моралната страна на поединецот. Иако овие термини можат да се заменат меѓусебно, терминот faqe повеќе ја означува моралната страна на индивидуата (Si ke fytyrë të më dalësh para!' Како имаш лице да ми излезеш пред очи!'; Doli me faqe të bardhë. 'Излезе со чист образ').

Очигледно е дека во секоја култура работата на лицето функционира различно, т.е. различни чинови се сметаат за ЧЗЛ, а други за чинови кои го зачувуваат лицето, но во секоја култура кога има ризик од некој ЧЗЛ почнува работа на лицето за да се избегнат недоразбирања или „инциденти“.

Друг лингвист кој се занимавал со теоријата на учтивост е Џефри Лич. Tој ја дефинира учтивоста како стратешко избегнување на конфликт, кое може да се мери со степенот на вложениот напор во тоа избегнување (Leech 1983: 19).

Лич наведува шест максими на принципите на учтивост спрема кои се водат соговорниците во која било комуникација. 
Од особена важност за овој труд се максимайа на сог̄ласување (минимизирај го несогласувањето меѓу себе и другиот/ максимизирај го

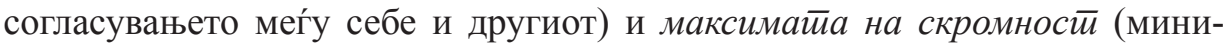
мизирај ја самопофалбата/максимизирај ја пофалбата за другиот), кои треба да се почитуваат при одговор на даден комплимент бидејќи и двете се спротивставуваат, со што го ставаат адресатот под одреден притисок правилно да ги балансира.

Според Браун и Левинсон (1987: 13), учтивоста претставува сложен систем за ублажување на закани за лицето, кое пак се состои од две страни

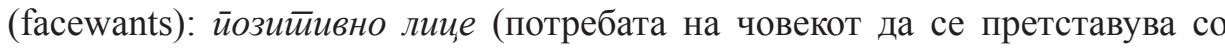
позитивна слика за себе за да биде прифатен од другите), и нег̄айивно лице (потребата на човекот за ненаметнување).

Во овој контекст, Браун и Левинсон сметаат дека сите говорни чинови претставуваат ЧЗЛ со самото тоа што го загрозуваат или позитивното или негативното лице. Бидејќи предметот на истражување на овој труд се комплиментите и нивните одговори, ќе истакнеме дека комплиментите претставуваат закана за негативното лице на адресатот со тоа што му сигнализираат дека давателот на комплиментот посакува нешто што нему му припаѓa (Brown and Levinson 1987: 66). Одговорите на комплиментите пак, претставуваат закана за негативното лице на давателот на комплиментот бидејќи на овој начин тој прифаќа долг кон адресатот. Прифаќањето на комплиментот директно го оштетува позитивното лице на примателот бидејќи тој може да се чувствува принуден да го омаловажи предметот за кој добил комплимент од говорителот и на овој начин да го оштети неговото лице или пак, може да се чувствува обврзан да му возврати на говорителот со комплимент (Brown and Levinson 1987: 67).

Друг лингвист кој се занимава со теоријата на учтивост е Џенет Холмс (Holmes 2001), чии истражувања за говорните чинови, особено за давањето и одговори на комплименти, претставуваат појдовна точка во овој труд.

\section{2 Говорниот чин на давање и одговарање на комплименти}

Различни автори (Pomerantz 1978, Holms 1986, Herbert 1990, Chiang and Pochtrager 1993, Yakimova 2012) за анализа на одговорите на комплиментите користат свои класификации на стратегиите за одговарање на комплименти. Секако дека при нивна анализа се зема предвид целата секвенца на говорниот чин на давање комплименти односно говорниот настан, како што го опишува Херберт (Herbert 1990: 202): 
А дава комплимент на Б

Б признава дека А го дал комплиментот

Херберт (Herbert 1990) разликува 12 стратегии на одговори на комплиментите, а Холмс (Holmes 1986: 492) ги анализира одговорите на комплиментите според три главни категории, кои ги дели во 12 поткатегории. Во овој труд, како основа на нашата класификација, ја земаме класификацијата на Холмс (Holmes 1986), но ја прошируваме со дополнителни категории и поткатегории. Секоја категорија опфаќа неколку стратегии (поткатегории) како одговор на комплиментот.

\section{1 Стратегии на одговори на комплименти}

\section{Прифаќање комплимент}

Прифаќањето на комплиментот може да се постигне со употреба на 6 стратегии наведени подолу со примери. Кратенките Г и С означуваат говорник (Г) и соговорник $(\mathrm{C})$.

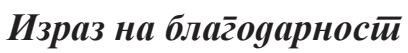

(1) Г: Какви убави очи имаш.

С: Фала.

\section{Исказ на сойласување}

(2) $\Gamma$ : Fillimin e ki pas... je mar me kutija edhe hala i ki ato kutija shumë t'bukra. 'Почетокот ти беше... се занимаваше со кутии и сѐ уште тие кутии ти се многу убави.'

C: Po, t’tezetshme. 'Да, слатки.'

\section{Исказ на минимизирање}

(3) Контекст: две наставнички коментираат за изгледот на помладата колешка во нејзино присуство.

Г: Shikoje sa e mirë është. 'Види ама е убава.'

C: (buzëqesh) Sherku. (се насмевнува) 'Од пудрата.'

\section{Возвраќање со комйлименй}

(4) $\quad$ : Стварно си многу брза.

С: И ти си многу мирна. 


\section{Максимизирање на йофалбайа}

(5) $\quad$ : Вие сте пионери и ветерани, тоа реков дека сте меѓу првите кои го разработивте и ја направивте оваа шема.

С: Не меѓу првите. Први. Има разлика.

Невербално иррифаќање (насмевка, кимнување во знак на одобрување, говор на телото и сл.).

(6) Г: Јас искрено не знам ни што работите, ни кај работите, но јас го знам чичко Данило хроничарот на Скопје со најтоплите и најпрекрасни приказни што ги слушам.

C: (се насмевнува).

\section{Одбивање комплимент}

\section{Исказ на несог̄ласуване}

(7) Г: Sa mirë po të rrika xhaketi. 'Ама убаво ти стои кошулата'

C: (buzëqesh), Prej zorit. (се насмевнува) 'Од зорт.'

\section{Исииийување на йочносйа}

(8) $\Gamma$ : Ty tani që të shoh që je vesh me këtë stilin tënd... Për mu është një gjë klasike... është art. 'Тебе кога те гледам сега облечен во овој твој стил... За мене е нешто класично...уметност е.'

C: Është mirë apo keq? 'Добро е или лошо?'

\section{Предизвкување на искреносӣа}

(9) $\quad$ : Пристрасна сум. Јас ќе кажам сѐ најубаво од секогаш.

$\mathrm{C}$ : Ама кажа пристрасна сум. Значи ич не сум добра.

\section{Избегнување комплимент}

\section{Пренасочување на ӣризнаниейо}

(10) Г: Имате преубава коса.

С: Вие сте заслужни за тоа.

\section{Информайивен коменйар}

(11) $\Gamma$ : Sa orën e mirë e paske. 'Ама убав саат имаш.'

C: Arta ma ka ble për n’punë. 'Арта ми го купи за на работа.' 


\section{Ӣ̄нориране}

(12) $\quad$ : Секогаш разговорот со тебе вреди да се сними да го видат и други.

C: (не реагира)

Прифайливо избег̄нување (оваа стратегија во одредени случаи во нијанси се разликува од Информайивен коменйар)

(13) $\Gamma$ : Ta kam inat se si i arrin të gjitha pa ndihmën e askujt.

'Ти завидувам како успеваш да постигнеш сѐ без ничија помош.'

C: E kemi për obligim të kujdesemi për familjen me çdo kusht.

'Обврска ни е да се грижиме за семејството по секоја цена.'

\section{Барање на йовйорување}

(14) Г: Навистина сте... морам да признаам најпријатното изненадување во овие локални избори.

$\mathrm{C}:$ Навистина?

\section{Ше̄̄a}

(15) $\quad$ : Велат дека реткост е и убава и паметна, а ти припаѓаш

баш во оваа група бидејќи те имам запознаено.

С: (се смее) Две во едно, нескафе.

\section{Единечни случаи на интерпретација на комплименти}

Во оваа стратегија ги групираме сите одговори кои не спаѓаат во ниту една од горе спомнтатите категории (на пр. подарување на предметот за кој е даден комплимент, изразување желба, употреба на секојдневни идиоматизирани изрази и сл.).

(16) Г: E paske këmishën shumë të mirë. 'Имаш многу убава кошула'

C: E blefsh më të mirë. 'Поубава да си купиш.'

\section{Комбинирани стратегии}

Оваа стратегија ги опфаќа сите одговори кои содржат комбинација на две

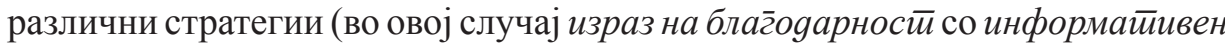
коменйар).

Г: Kqyre sa e bukur. 'Види ама е убава'

C: Faleminderit. Jom ndreç për juve. 'Благодарам. Се средив за вас' 
Горната класификација се разликува од класификацијата на Холмс по тоа што се додадени две категории: gруг̄a иниеерӣрейација и комбинирани

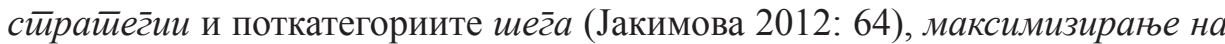
йофалбайа (Herbert 1990: 208) и невербално иррифаќање, стратегија која

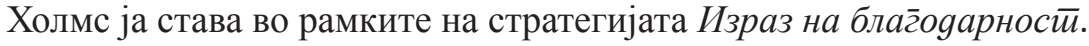

\section{2 Функцијата на комплиментите}

Според Холмс (Holmes 1986: 486), главната функција на комплиментите е афективна - како позитивно афективни говорни чинови тие служат за зголемување или консолидирање на солидарноста меѓу говорителот и адресатот. Една друга многу важна функција на комплиментите е општествената. Тие се општествени „подмачкувачи“ кои служат за креирање или за одржување на комуникацијата (Wolfson 1983: 86), или за зголемување, или зацврстување на солидарноста меѓу луѓето (види Holmes 1988: 462).

Во долунаведениот пример преземен од корпусот се покажува дека прегратката ја покажува оваа функција на комплиментот.

(18) Контекст: домаќинка при поздравување со нејзината гостинка на влезот во нејзиниот стан:

Домаќинка: z. Antigonë si jeni? A Jeni mirë? Shumë bukur po dokeni. 'Г-ѓа Антигона како сте? Добро? Многу убаво изгледате.'

Гостинката: (Не реагира само ја прегрнува).

Друга функција на комплиментите е и референцијална. Имено, преку комплиментите се пренесуваат информации за одредено „добро“ што говорителот одлучува да го коментира (Holmes 1995: 118). Следи примерот.

(19) Контекст: Пријателка коментира за блузата

што ја носи нејзината другарка.

Г: Sabluzamirë.'Ама убава блуза'

C: Mami ma ka ble. ' Мама ми ја купи.'

Во истражувањето за комплиментите во Америка, Херберт (Herbert 1990: 221) истакнува дека меѓу другите функции, комплиментите имаат и функција на изразување восхит и пофалба. Како што ке забележиме и во примерите од корпусот, изгледа дека и во албанската и во македонската култура изразувањето восхит е една од функциите на комплиментите, како што го илустрира долунаведениот пример:

\footnotetext{
Автентичен говор, Куманово, 2013.
} 
(20) Контекст: разговор меѓу двајца мажи за достигањата на постариот во управување со еден реномиран ресторан.

Г: Aki, njerëz si ju njëherë lindin.'Аки, луѓе како вас еднаш се раѓаaт.' $\mathrm{C}:$ (се насмевнува)

И пофалбата е една очигледна функција на комплиментите, и ако ги анализираме комплиментите со ваква функција, може да се каже дека речиси секогаш се даваат од поединци со надреден општествен статус или поголема возраст. Целта на давање комплименти за фалење некого може да биде признание или стимулирање на одредено однесување на адресатот.

(21) Контекст: учителката пред сите ученици го коментира однесувањето на 6-годишната ученичка која претходно постојано плачеше а сега е мирна.

Г: Shikone Elmën sa drejt rri ulur. 'Гледајте ама исправено седи Елма' C: (не зборува само уште повеќе се исправува за да ја видат сите)²

Ако се земе предвид и теоријата на учтивост на Браун и Левинсон (Brown and Levinson 1987), ќе забележиме дека комплиментите служат како стратегии за извршување позитивна учтивост, посебно во случаи кога еден исказ се смета за ЧЗЛ. Во оваа смисла, тие може да се користат и во случаи на давање критики, при што го ублажуваат ефектот на таков ЧЗЛ. Следниот пример го илустрира тоа:

(22) Контекст: Во емисија модераторот ѝ ги пренесува на гостинката (пејачка) коментарите од социјалните мрежи.

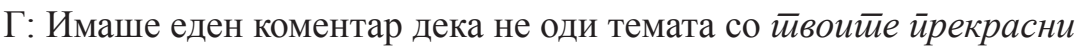
нозе кои ги видовме претходно.

$\mathrm{C}$ : Не мислам така, ама добро (се смее) $)^{3}$.

Во рамките на оваа теорија ќе ја наведеме и другата функција на комплиментите, а тоа е дека овој чин, сам по себе го загрозува лицето на соговорникот. И Холмс (1986) и Херберт (1990) го наведуваат фактот дека во одредени култури давањето комплимент за одредено „добро“ што го поседува адресатот, сигнализира дека говорителот го посакува тоа „добро“ и на овој начин го загрозува негативното лице на адресатот. Ова добро се гледа во следниот пример, каде што адресатот токму така го сфатил комплиментот и реагира великодушно со подарување на предметот.

2 Автентичен разговор во ОУ,ФФик Коница“, с. Слупчане, Липково 2013.

3 Автентичен говор, емисија Carpediem, Алсат-М, 2013. 
(23) Контекст: две братучетки се поздравуваат при заминување.

$\Gamma$ : Sa kapelën e mirë e paske. 'Ама убава капа имаш'

C: (e heq nga koka) E gëzofsh.

(ја вади од глава) 'Со здравје да ја носиш.'

Како ЧЗЛ се сметаат и тие комплименти кои се „неискрени“ или иронични, како и комплиментите од страна на непознати, флертувањата и сл. Таквите комплименти не се придржуваат до максимата за квалитет (Yule 1996: 35), која бара исказот да биде вистинит за остварување на успешна комуникација, но, исто така, крши и едно од правилата неопходни за правилно разбирање на еден говорен чин, а тоа е правилото за искреност (Yule 1996: 35).

\section{3 Говорните чинови и културата}

Јазикот и културата се поврзани меѓу себе, бидејќи учењето на еден јазик не значи само учење на зборовите и нивното значење, нивната точна комбинација со други зборови и како се изговараат, туку треба да се знае и што значат тие зборови во тој културен контекст каде што се употребуваат (Холмс 2001: 275).

Овој став на Холмс ме потсетува на една моја сопствена грешка, кога случајно наслушнав разговор меѓу две жени (Македонки):

$$
\begin{aligned}
& \text { Г: Леле, баш си се поправила! } \\
& \text { С: (го гледа сопственото тело) Да, да (со засрамена насмевка) }
\end{aligned}
$$

Поради влијанието на мојот мајчин јазик (албанскиот) овој говорен чин погрешно го протолкував како комплимент од незнаењето дека во македонскиот јазик „некој да се поправи“ (во однос на телесната тежина) се употребува како еуфемизам за „здебелување“. Во албанскиот јазик, да се каже некому 'Qenke përmirësuar' би се сметал за комплимент и најчесто се употребува кога сакаме некого да 'пофалиме' дека се подобрил во однос на изгледот.

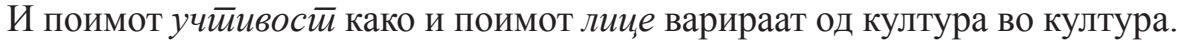
Во оваа смисла и комплиментите и одговорите на комплиментите зависат од културата и ги рефлектираат нивните вредности. Интересен пример е изразот „You're so fat!” (Многу си дебел/a!), кој во мнозинството култури, вклучувајќ ги албанската и македонската, би се третирал како навреда и со тоа ЧЗЛ, додека во културата на племето Оџибве се третира како

4 Автентичен говор, Куманово 2014 (преземен од корпусот). 
комплимент (Spielman 1998: 30). Во Саудиска Арабија, по јадењето, гостите ждригнуваат како знак на комплимент за готвачот, што во европските култури се смета за вулгарно и непристојно. Во американската култура, на пример секојдневниот разговор се очекува да биде исполнет со комплименти кои често се перципираат за неискрени, а очекуваниот одговор е thank you 'благодарам' (Herbert 1990: 207). Ова сугерира дека американската култура се базира на воспоставување добри односи, додека во Јужна Африка случајот е сосема спротивен - комплименти се даваат само кога се смета дека е заслужен. ${ }^{5}$ Во кинеската култура пак, која се карактеризира со понизност и скромност, да се прифати комплимент ќе сигнализира дека соговорникот се смета за супериорен во неговата група. ${ }^{6}$ Слични културни вредности во овој поглед има и јапонската култура (Tsuda 1992: 137) и тајландската (Cedar 2006), кои исто така се карактеризираат со понизност. Ова укажува на фактот дека култури кои делат ист континент делат донекаде и слични вредности.

\section{4 Методологија на истражувањето}

Во овој труд е употребен методот на контрастивна анализа на добиените податоци заради тоа што главна цел е опис и споредба на стратегиите на одговори на комплименти во три различни култури: албанската, македонската и англиската.

Истражувањето се состоеше од неколку фази:

- собирање на податоци за корпус, кој е собран на два начина: преку запишување на реакции на комплименти во реални ситуации и преку прашалник со ситуации.

- класификација на податоците, кои ги анализиравме според неменливите категории: етникум, пол и возраст.

- квантитативна анализа, каде што можевме да ги утврдиме разликите и сличностите во одговорите зависно од трите неменливи категории кои ги спомнавме.

- споредба на резултатите со англиските податоци, односно со податоците од истражувањата на Холмс (Holmes, 1986, 1988) и Херберт (Herbert 1990).

$5 \mathrm{http} / / /$ separatedbyacommonlanguage.blogspot.com/2008/06/compliments-nice-and-lovely.html

6 http://www.management-issues.com/opinion/6548/compliments-and-cultural-intelligence/ 
Во однос на инструментите, за да имаме увид како се одговара на комплиментите и во реални ситуации, составен е и втор корпус со вкупно 100 примери од говорниот чин на давање и одговарање на комплименти од страна на македонски и албански говорители. Овие примери се собрани од телевизиски емисии, слушнати разговори, разговори иницирани од самиот истражувач за да „изнуди“ одговор на комплиментот од соговорникот. Така, од телевизиските емисии собрани се вкупно 79 комплименти - од 64 албански и македонски емисии (другите 21 примери се од секојдневниот живот). Овие комплименти се запишани како што се слушнати, без никакви промени.

За да биде истражувањето поконзистентно, направивме прашалник со ситуации (ПС, англиски DCT), кој е ист и за албански и за македонски испитаници. Тој е дистрибуиран меѓу испитаници од различна возраст, пол и социјален статус и во двете јазични заедници за да се види во понатамошната анализа дали националната култура и гореспоменатите фактори влијаат врз изборот на одговорите на комплиментите.

Во прашалникот со ситуации, креирани се 11 ситуации со комплименти на кои испитаникот треба да одговори на начин на кој би одговорил во реалниот живот. При креирање на ситуациите со комплимент земени се предвид темата на комплиментот и полот на говорителот.

Иако прашалникот не е секогаш најсоодветен за собирање податоци поради тоа што ситуациите не се реални и не се користи устен говор, сепак, тој се покажа како многу корисен бидејќи ни овозможи да видиме како испитаници од различен етникум и пол и различна возраст реагираат на ист комплимент.

Во пополнувањето на прашалниците со ситуациите учествуваа вкупно 120 лица од кои 60 од албанската националност и 60 од македонската. Во истражувањето беа опфатени мажи и жени, групирани во две старосни групи според возраст: млади (од 18 до 40 години) и постари (над 40 години) независно од полот. Друга варијабла која е предмет на анализа е и категоријата пол.

\section{5 Анализа на одговорите на комплиментите според категориите етникум, пол, возраст и тема на комплимент}

\section{1 Анализа на одговорите на комплиментите од КРС}

Во овој дел од истражувањето преку табеларни прикази и нивна анализа се прикажани одговорите на комплиментите, а воедно е направена и трипартитна компарација каде што ги вклучивме и англиските податоци од 
истражувањето на Холмс во Нов Зеланд (види Табела 1 и Табела 2). Бројот на примери во нејзиното истражување е многу поголем од примерите во нашиот корпус (517 наспрема 38 и 62) и затоа споредбите меѓу овие три јазици се направени во однос на процентите. Оваа трипартитна компарација на резултатите е направена само со корпусот на реални ситуации бидејќи во нејзиното истражување Холмс користи само реални ситуации.

Првата анализа е направена врз основа на главните категории на одговори на комплименти во албанскиот, македонскиот и англискиот јазик (види Слика 1).

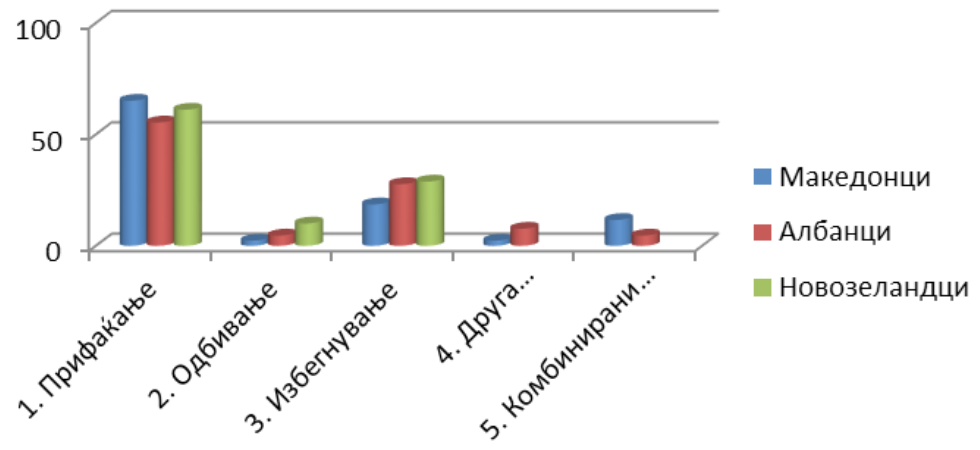

Слика 1: Дистрибуција на одговорите на говорителите

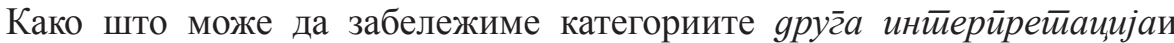
комбинирани сиирайег̄uи се застапени само кај албанскиот и македонскиот корпус не поради тоа што не постојат примери од вакви видови на одговори во англискиот туку поради тоа што Холмс ги класификува одговорите на комплиментите врз основа на првите три категории. Значи, ако ги споредиме одговорите на комплиментите во однос на првите три категории ќе забележиме сличности меѓу овие три јазика: претпочитаниот одговор во овие три култури е прифаќање на комплиментот, а необично е одбивање на дадениот комплимент.

Во однос на претпоставката дека полот на говорителот влијае врз начинот на кој се одговара на комплимент, таа не се потврди бидејќи без разлика на тоа дали говорителот е маж или жена претпочитаниот одговор на еден комплимент е секогаш прифаќање.

Кога ги анализиравме одговорите на комплиментите во однос на стратегиите, можевме да забележиме повеќе сличности отколку разлики, особено меѓу албанската и македонската култура. 
Табела 1. Стратегии на одговори на комплименти во македонскиот и во албанскиот КРС

\begin{tabular}{|c|c|c|c|c|}
\hline Стратегии & Македонци & $\%$ & Албанци & $\%$ \\
\hline \multicolumn{5}{|l|}{ 1. Прифаќање } \\
\hline 1.1 Израз на благодарност & 14 & 32,6 & 14 & 21,5 \\
\hline 1.2 Исказ на согласување & 4 & 9,3 & 3 & 4,6 \\
\hline 1.3 Исказ на минимизирање & & & 2 & 3,1 \\
\hline 1.4 Возвраќање со комплимент & 1 & 2,3 & 2 & 3,1 \\
\hline 1.5 Максимизирање на пофалбата & 1 & 2,3 & 2 & 3,1 \\
\hline 1.6 Невербално прифаќање & 8 & 18,6 & 13 & 20 \\
\hline \multicolumn{5}{|l|}{ 2. Одбивање } \\
\hline 2.1 Исказ на несогласување & & & 2 & 3,1 \\
\hline 2.2 Испитување на точноста & & & 1 & 1,5 \\
\hline 2.3 Предизвикување на искреноста & 1 & 2,3 & & \\
\hline \multicolumn{5}{|l|}{ 3. Избегнување } \\
\hline \multicolumn{5}{|l|}{3.1 Пренасочување на признанието } \\
\hline 3.2 Информативен коментар & & & 5 & 7,7 \\
\hline 3.3 Игнорирање & 2 & 4,7 & 9 & 13,8 \\
\hline 3.4 Прифатливо избегнување & & & 2 & 3,1 \\
\hline 3.5 Барање на повторување & 2 & 4,7 & 1 & 1,5 \\
\hline 3.6 Шега & 4 & 9,3 & 1 & 1,5 \\
\hline 4. Друга интерпретација & 1 & 2,3 & 7 & 10,8 \\
\hline 5. Комбинирани стратегии & 5 & 11,6 & 1 & 1,5 \\
\hline Вкупно & 43 & 100 & 65 & 100 \\
\hline
\end{tabular}

Како што може да се забележи од Табела 1, најчесто се прифаќа ком-

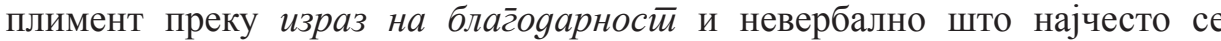
изразува преку насмевка или кимнување, а најретко се одбива комплимент.

Може да сезабележи дека постојат стратегии кои воопшто не се користени во македонскиот корпус, но причината веројатно лежи во малиот број на примери. Најголеми разлики се забележуваат во употребата на стратегиите иг̄норирање (кај Македонците е 5\%, а кај Албанците е 14\%) и шег̄a која многу повеќе ја користат Македонците во споредба со Албанците.

Како што споменавме, во корпусот со реалните ситуации направена е анализа и според полот и возраста на соговорникот, но не се пронајдени 
значителни разлики меѓу половите во изборот на стратегиите на одговори на комплименти. И двата пола се склони кон прифаќање на комплиментот преку израз на благ̄ogapносӣ, а најмалку кон негово одбивање. Во македонскиот корпус тоа што е позабележително е стратегијата исказ на сог̄ласување, која повеќе ја користат мажите, и стратегијата невербално йрифаќање, која повеќе се користи од жените. Во албанскиот корпус позначителни разлики има во категоријата gруг̄a инӣерӣрейација, која повеќе ја користат мажите. Во седум стратегии не се застапени мажите, но ова најверојатно се должи на фактот дека бројот на мажи адресати во албанскиот корпус беше многу мал во споредба со тој на жените.

Табела 2. Дистрибуција на стратегиите на одговори на комплименти во англискиот корпус на Холмс (Holmes 1986: 495)

\begin{tabular}{|l|c|c|}
\hline \multicolumn{1}{|c|}{ Стратегии } & Новозеланѓани & \% \\
\hline 1. Прифаќање & & \\
\hline 1.1 Израз на благодарност & 73 & 15,3 \\
\hline 1.2 Исказ на согласување & 157 & 32,8 \\
\hline 1.3 Исказ на минимизирање & 44 & 9,2 \\
\hline 1.4 Возвраќње со комплимент & 18 & 3,8 \\
\hline 2. Одбивање & & \\
\hline 2.1 Исказ на несогласување & 32 & 6,7 \\
\hline 2.2 Испитување на точноста & 12 & 2,5 \\
\hline 2.3 Предизвикување на искреноста & 4 & 0,8 \\
\hline 3. Избегнување & & 1,3 \\
\hline 3.1 Пренасочување на признанието & 6 & 8,8 \\
\hline 3.2 Информативен коментар & 42 & 3,3 \\
\hline 3.3 Игнорирање & 16 & 10,4 \\
\hline 3.4 Прифатливо избегнување & 50 & 5 \\
\hline 3.5 Барање на повторување & 24 & 100 \\
\hline Вкупно & 478 & \\
\hline
\end{tabular}

Иако Херберт (Herbert 1990) тврди дека претпочитаниот одговор на еден комплимент на англиските говорители е Благ̄ogapaм се гледа дека ова тврдење повеќе важи за нашата средина отколку за некоја англофонска земја. Во овој корпус најкористена стратегија е исказ на содлласување, што ни сугерира дека кај Новозеланѓаните акцент се става на согласување со 
говорителот, т.е. се води сметка за максимата на согласување, додека пак кај Албанците и Македонците се става акцент на максимата на скромност. И во англискиот корпус не се забележуваат разлики меѓу половите во изборот на стратегии на одговорите на комплименти: и мажите и жените најчесто го прифаќаат комплиментот и тоа преку исказ на сог̄ласување, а најретко го одбиваат преку йреgизвикување на искреностй. Ако ги споредиме трите табели во целина, забележуваме дека податоците од албанскиот и од македонскиот корпус имаат доста сличности, а се разликуваат од англискиот, како што и се предвидуваше. Во категоријата йрифаќање, за разлика од англискиот корпус каде што стратегиите исказ на минимизирање и возвраќање со комйлименй се застапени од двата пола (иако во мал процент), во албанскиот и во македонскиот корпус овие стратегии не се користени од мажите во ниту една ситуација. Истото може да се каже и за категориите оgбивање и избегінување каде што не е регистрирана ниту една ситуација во која мажите употребиле исказ на несогласување, ја предизвикале искреноста на говорителот или давале информативен коментар за предметот-целта на комплиментот.

Најголемата сличност меѓу трите етникуми се забележува во категоријата üpuфaќaґе, каде што жените возвраќале со комплимент со иста застапеност $(4 \%)$.

Според ова може да заклучиме дека постојат многу сличности меѓу албанскиот и македонскиот корпус, а овие два се разликуваат од англискиот.

Кога ќе ги споредиме овие податоци со тие на Херберт (1990), кој прави истражување со американска популација, ќе видиме дека Американците се послични со Албанците и Македонците отколку Новозеланѓаните.

Овие податоци се анализирани и од аспект на теоријата на учтивост на Браун и Левинсон. Сепак, за да донесам заклучоци во однос на оваа теорија, повеќе се потпирав на податоците од корпусот изведен од прашалниците каде што има посолидна база на податоци.

Во однос на темата на комплимент поконцизни резултати добивме од анализата на корпусот изведен од прашалниците каде што направивме и паралелна споредба со резултатите од корпусот изведен од реалните ситуации.

\section{2 Анализа на одговорите на комплиментите од КПС}

Овој корпус претставува посолидна база на податоци за анализа во споредба со корпусот од реалните ситуации. Корпусот содржи вкупно 1320 искази од кои 660 се на македонски и 660 на албански. 
Првата анализа на исказите е спроведена врз основа на етникумот на испитаниците чиишто резултати ги подржуваат резултатите од корпусот со реалните ситуации (види Табела 3 ).

Табела 3. Дистрибуција на одговорите на комплиментите во македонскиот и во албанскиот КПС

\begin{tabular}{|l|c|c|c|c|}
\hline \multicolumn{1}{|c|}{ Стратегии } & Македонци & \% & Албанци & \% \\
\hline 1. Прифаќање & 203 & 30,8 & 181 & 27,4 \\
\hline 1.1 Израз на благодарност & 139 & 21,1 & 107 & 16,2 \\
\hline 1.2 Исказ на согласување & 13 & 2,0 & 20 & 3,0 \\
\hline 1.3 Исказ на минимизирање & 30 & 4,5 & 35 & 5,3 \\
\hline 1.4 Возвракање со комплимент & 2 & 0,3 & 3 & 0,5 \\
\hline 1.5 Максимизирање на пофалбата & 12 & 1,8 & 5 & 0,8 \\
\hline 1.6 Невербално прифакање & 7 & 1,1 & 11 & 1,7 \\
\hline 2. Одбивање & 13 & 2,1 & 28 & 4,2 \\
\hline 2.1 Исказ на несогласување & 7 & 1,1 & 23 & 3,5 \\
\hline 2.2 Испитување на точноста & & & 1 & 0,2 \\
\hline 2.3 Предизвикување на искреноста & 6 & 1,0 & 4 & 0,6 \\
\hline 3. Избегнување & 138 & 20,9 & 181 & 27,4 \\
\hline 3.1 Пренасочување на признанието & 16 & 2,4 & 9 & 1,4 \\
\hline 3.2 Информативен коментар & 56 & 8,5 & 84 & 12,7 \\
\hline 3.3 Игнорирање & 27 & 4,1 & 38 & 5,8 \\
\hline 3.4 Прифатливо избегнување & 26 & 3,9 & 42 & 6,4 \\
\hline 3.5 Барање на повторување & 2 & 0,3 & 5 & 0,8 \\
\hline 3.6 Шега & 11 & 1,7 & 3 & 0,5 \\
\hline 4. Друга интерпретација & 12 & 1,8 & 32 & 4,8 \\
\hline 5. Комбинирани стратегии & 294 & 44,5 & 238 & 36,1 \\
\hline Вкупно & 660 & 100 & 660 & 100 \\
\hline
\end{tabular}

Позабележителни разлики меѓу етникумите во користењето на овој говорен чин има во категоријата избегінување, која повеќе ја користат Албанците и категоријата комбинирани сӣрайег̄uи која повеќе ја користат Македонците. Во споредба со КРС има неверојатно слични проценти во категориите оябивање, избег̄нување и gруг̄а иниеериретйација, а значителни разлики има во категоријата йрифаќање која бележи двојно понизок процент на користеност од таа во КРС и категоријата комбинирани сиирайег̄uи, која бележи највисок процент на користеност особено во македонскиот КПС што 
сугерира дека и двете култури при одговори на комплименти преферираат да користат посложени структури. Ако не се земе предвид оваа категорија ќе забележиме дека и двете култури најчесто одговараат на комплимент преку заблаг̄ogaрување (faleminderit, faleminderit për komplimentin, фала,

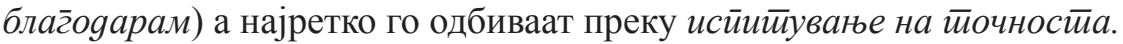

Втора по ред најкористена стратегија е информайивен коменйар, што е спротивно од резултатите од КРС. Во однос на полот не постојат разлики меѓу мажите и жените во изборот на стратегиите за одговор на комплименти. Во македонскиот корпус единствена позначителна разлика меѓу половите е користењето на стратегијата шег̄a која најчесто ја користат мажите во споредба со жените за да избегнат комплимент. И за албанскиот корпус може да се каже дека полот не влијае врз изборот на стратегијата на одговор на комплимент, освен тоа што мажите најчесто избегнуваат комплимент преку информативен коментар (највисок процент 15\%), додека пак жените го прифаќаат преку заблагодарување.

Ако се споредат со КРС, најголема разлика има во однос на стратегиите невербално ӥрифаќање и стратегијата информайивен коменӣар, која во КПС бележи многу висок процент, а во КРС воопшто не е користена. Причината за несовпаѓање на резултатите кај двата етникума, особено во употребата на овие две стратегии може да се должи на фактот што едниот корпус е формиран од секојдневниот говорен јазик, каде што најчесто, особено во емисиите, нема простор за давање посложени одговори (информативен коментар), додека пак во КПС се користи само пишаниот јазик, па затоа има повеќе простор и време да се изразиме како што сакаме, но нема доволно средства за изразување на невербалното прифаќање на комплиментот.

Во однос на возраста, во македонскиот корпус се забележува нешто поголемо влијание врз начинот на одговори на комплименти, но кои, сепак, не укажуваат на претпочитан модел на одговори на комплименти според возраста.

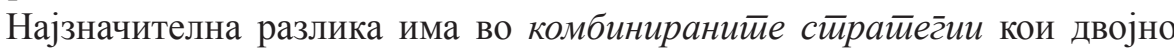
повеќе ги користат помладите мажи во споредба со постарите. Во албанскиот корпус разликите меѓу половите во однос на возраста се уште

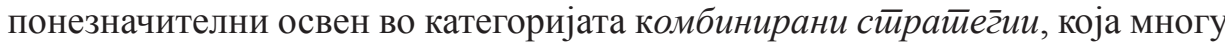
повеќе ја користат помладите мажи во споредба со постарите.

Поради високиот процент на користеност на оваа категорија, направивме посебна и подетална анализа на овие одговори на комплименти и тоа посебно за македонскиот корпус и посебно за албанскиот бидејќи во двата корпуса има различни видови на комбинации (види Табела 4 и Табела 5). Бројот на комбинирани стратегии е многу голем (кај Македонците има 31, а кај Албанците 21 комбинација на стратегии.) 
Табела 4. Комбинирани стратегии кај Македонците

\begin{tabular}{|c|l|c|c|}
\hline & \multicolumn{1}{|c|}{ Комбинирани стратегии } & Резултати & \% \\
\hline 1 & Израз на благодарност и исказ на согласување & 16 & 2,4 \\
\hline 2 & Израз на благодарност и исказ на минимизирање & 15 & 2,3 \\
\hline 3 & Израз на благодарност и возвраќње со комплимент & 22 & 3,3 \\
\hline 5 & Израз на благодарност и информативен коментар & 92 & 13,9 \\
\hline 6 & Израз на благодарност и прифатливо избегнување & 15 & 2,3 \\
\hline 7 & Израз на благодарност и друга интерпретација & 72 & 10,9 \\
\hline
\end{tabular}

Табела 5. Комбинирани стратегии кај Албанците

\begin{tabular}{|c|l|c|c|}
\hline & \multicolumn{1}{|c|}{ Комбинирани стратегии } & Резултати & \% \\
\hline 1 & Израз на благодарност и исказ на минимизирање & 24 & 3,6 \\
\hline 2 & Израз на благодарност и возвраќње со комплимент & 9 & 1,4 \\
\hline 3 & Израз на благ. и пренасочување на признанието & 8 & 1,2 \\
\hline 5 & Израз на благодарност и информативен коментар & 66 & 10 \\
\hline 6 & Израз на благодарност и прифатливо избегнување & 17 & 2,6 \\
\hline 7 & Израз на благодарност и друга интерпретација & 71 & 10,8 \\
\hline
\end{tabular}

Највпечатливиот податок од двете табели е што една од стратегиите во комбинација е израз на благ̄ogaрносй, што ни укажува дека и двата етникума внимаваат да укажат учтивост кон соговорникот и во случаи кога комплиментот не се прифаќа. Заблагодарувањето во овој случај не служи за прифаќање на комплиментот туку за ублажување на несогласувањето и за оддавање признание на говорителот дека го цени комплиментот иако не го прифаќа. Кај Македонците најупотребувана комбинирана стратегија е израз


на сите стратегии, а во албанскиот корпус забележуваме дека најкористена


изборот на комбинираните стратегии на одговори на комплименти според полот можеме да заклучиме дека полот не влијае врз изборот на стратегиите колку што влијае националната култура.

Во однос на возраста, и кај комбинираните стратегии се забележува дека возраста влијае малку повеќе од полот во изборот на стратегиите, како што 



коменйар, кој значително повеќе го користат македонските млади мажи во споредба со постарите. Истото важи и за комбинираните стратегии во албанскиот корпус, но тука резултатите кај женската популација се подискриминирачки поради фактот што процентот на одговори дадени од постари жени е драстично помал (76\% млади наспрема 24\% постари жени). Овие податоци не се прикажани табеларно поради фактот што нема некои значителни разлики кои укажуваат на културни закономерности.

Последната точка во анализата на одговорите на комплиментите од корпусот изведен од прашалниците е таа според темата на комплимент за која претпоставувавме дека ќе ни овозможи да осознаеме повеќе за одговорите на комплиментите во рамките на теоријата на учтивост, т.е. кои теми се сметаат за ЧЗЛ и како се постапува кон нив.

Иако на прв поглед изгледа дека комплиментите за изглед најчесто

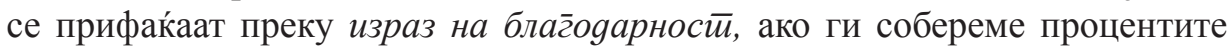
од стратегијата информаиивен коменйар со наведената комбинирана стратегија, што е нејзина поблага варијанта на избегнување, тогаш ќе видиме дека најчестиот одговор на еден комплимент за надворешниот изглед е негово (учтиво) избегнување преку информативен коментар. Кога правиме споредба меѓу мажите и жените, резултатите не се изненадувачки - жените најмногу одговараат на комплимент преку израз на благ̄оgарносӣ, додека

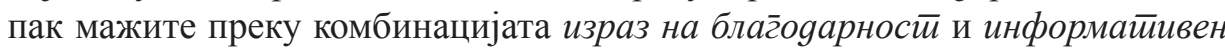
коменіиар. Преференциите во изборот на стратегиите во однос на темата изг̃леg се јасен индикатор на сличностите меѓу Албанците и Македонците (види Табела 6).

Табела 6. Тема изглед

\begin{tabular}{|l|c|c|}
\hline \multicolumn{1}{|c|}{ Стратегија } & Македонски КПС & Албански КПС \\
\hline Израз на благодарност & $25 \%$ & $22,8 \%$ \\
\hline Информативен коментар & $9,4 \%$ & $13,9 \%$ \\
\hline $\begin{array}{l}\text { Израз на благодарност и } \\
\text { информативен коментар }\end{array}$ & $18,3 \%$ & $16,7 \%$ \\
\hline
\end{tabular}

И во однос на темата имой може да забележиме сличности меѓу албанската и македонската култура во изборот на стратегиите при одговор на комплимент (види Табела 7). Комплиментите од овој тип најчесто се прифаќаат преку израз на благ̄ogарносй. Друга сличност меѓу етникумите е изборот на стратегиите во однос на полот. И македонските и албанските 


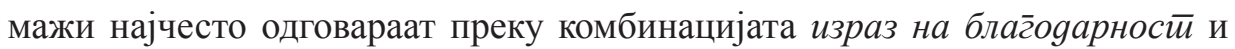
gруг̄a инйерӣрейација (каде што спаѓаат секојдневни конвенционални изрази), додека пак жените преку заблагодарување.

Табела 7. Тема имот/поседување

\begin{tabular}{|l|c|c|}
\hline \multicolumn{1}{|c|}{ Стратегија } & Македонски КПС & Албански КПС \\
\hline Израз на благодарност & $22,8 \%$ & $20 \%$ \\
\hline $\begin{array}{l}\text { Израз на благодарност и } \\
\text { информативен коментар }\end{array}$ & $16,1 \%$ & $11,1 \%$ \\
\hline $\begin{array}{l}\text { Израз на благодарност и друга } \\
\text { интерпретација }\end{array}$ & $19,4 \%$ & $17,8 \%$ \\
\hline
\end{tabular}

Во однос на темата $c \bar{u} о с о б н о с \bar{u}$ (види Табела 8), може да забележиме дека комплиментите од овој тип во двете култури најчесто се избегнуваат

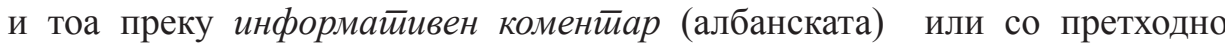
заблагодарување. Во однос на полот, тоа што паѓ во очи се изразите на благодарност кои двојно повеќе ги употребуваат жените во споредба со мажите.

Табела 8. Тема способност

\begin{tabular}{|l|c|c|}
\hline \multicolumn{1}{|c|}{ Стратегија } & Македонски КПС & Албански КПС \\
\hline Израз на благодарност & $14,6 \%$ & $12,9 \%$ \\
\hline Информативен коментар & $12,1 \%$ & $17,5 \%$ \\
\hline $\begin{array}{l}\text { Израз на благодарност и } \\
\text { информативен коментар }\end{array}$ & $12,5 \%$ & $6,7 \%$ \\
\hline $\begin{array}{l}\text { Израз на благодарност и друга } \\
\text { интерпретација }\end{array}$ & $13,8 \%$ & $13,8 \%$ \\
\hline
\end{tabular}

Во однос на темата личносӣ (види Табела 9), резултатите се разликуваат најмногу во споредба со другите теми. Во македонскиот корпус најголем

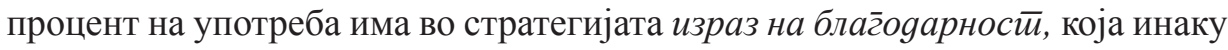
двојно повеќе се користи од жените. Кај Албанците највисок процент има во стратегијата иг̄норирање. Сепак, новото е исказ на минимизирање, кој подразбира и доза на несогласување и исказ на несог̄ласување, каде што има значителен процент на употреба. Во однос на полот, во албанскиот корпус интересно е што во само еден случај мажите прифатиле комплимент преку 
заблагодарување. Ова ни сигнализира дека за разлика од другите теми, комплиментите за личноста се толку чувствителни за лицето на примателот на комплимент што тој може да оди и до таа мера што ќе го оштети позитивното лице на давателот на комплимент преку негово одбивање.

Табела 9. Тема личност

\begin{tabular}{|l|c|c|}
\hline \multicolumn{1}{|c|}{ Стратегија } & Македонски КПС & Албански КПС \\
\hline Израз на благодарност & $30 \%$ & $10 \%$ \\
\hline Исказ на минимизирање & $25 \%$ & $15 \%$ \\
\hline Исказ на несогласување & $5 \%$ & $10 \%$ \\
\hline Игнорирање & $10 \%$ & $21,7 \%$ \\
\hline
\end{tabular}

\section{7 Заклучок}

Ова истражување е спроведено со цел да се согледаат разликите и сличностите кои постојат меѓу албанската, македонската и англиската култура во употребата на говорниот чин на одговарање комплименти, поконкретно стратегиите кои се употребуваат при одговор на дадениот комплимент.

Во однос на поставените хипотези, со истражувањето успеавме да ја потврдиме главната претпоставка дека постојат сличности во изборот на стратегии на одговори на комплименти меѓу македонската и албанската култура, па дури има сличности и со англиската. Преференција за полот на говорителот кој прима комплимент се јавува во сите три култури, поконкретно, жените се тие кои добиваат најмногу комплименти (потврда за англиската култура наоѓаме кајHolmes 1988: 449). Понатаму, во сите три култури претпочитаниот одговор на еден комплимент е прифаќње и тоа

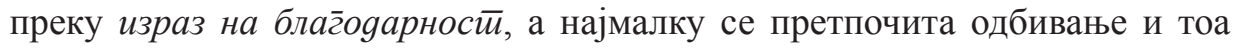

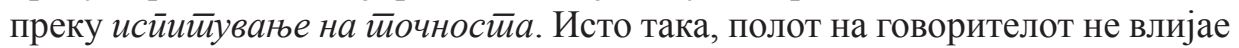
толку врз изборот на стратегијата на одговори на комплименти колку што влијае националната култура, односно, независно од полот, одговорот на еден комплимент е најчесто прифаќање (потврдено и во КПС и од КРС).

Што се однесува до втората претпоставка дека двете балкански култури се разликуваат од англиската во однос на овој говорен чин, успеавме да утврдиме дека во албанската и во македонската култура претпочитаниот одговор на еден комплимент е Благ̄ogapaм, додека во англиската култура најмногу се претпочитува да се прифати комплимент 
преку исказ на сог̄ласување. Ова ни укажува на фактот дека Албанците и Македонците повеќе водат сметка за максимата на скромност во споредба со Новозеланѓаните, кои повеќе внимаваат на почитување на максимата на согласување.

Во однос на третата претпоставка дека постојат разлики меѓу албанската и македонската култура, заклучивме дека постои разлика во избор на темите за комплиментот: во македонската култура како тема најчесто се


направи паралела меѓу американската култура, каде што според Wolfson (1983), најголемиот број на комплименти се дадени за способност и изглед, и новозеландската (Holmes, 1986), каде што се претпочита да се даваат комплименти за изглед. Сепак, не можеме да ги споредуваме балканската и „западната“" култура во овој поглед со оглед на недоволен број истражувања. Кога се избегнува комплимент (според КПС и КРС), Македонците (особено мажите) почесто тоа го прават преку шег̄ $a$ во споредба со Албанците, а македонските жени повеќе од албанските прифаќаат комплименти со изрази на благоодарносй.

Најголеми разлики меѓу КПС и КРС се забележуваат во користењето на категоријата йрифаќање и комбинирани стирайег̄ии каде што не се совпаѓаат процентуалните резултати.

Во однос на употребените стратегии се забележуваат разлики особено во користењето на стратегијата невербално иррифаќање и информайивен коменйар. Тоа се должи на фактот што во КРС најголемиот број ситуации беа земени од ТВ емисии, каде што најчесто се очекува да се биде краток и релевантен, а тоа подразбира и споделување информации од приватниот живот со другите, што секој не прифаќа да го направи во емисија. Во однос на невербалното прифаќање, факт е дека многу полесно се интерпретира говор на телото во реални ситуации отколку во пишан говор, што е еден од недостатоците на прашалникот со ситуациите.

\section{1 Заклучоци поврзани со теоријата на учтивост на Браун и Левинсон}

Користејќи ја теоријата на учтивост на Браун и Левинсон (Brown and Levinson 1978) во нашето истражување, успеавме да утврдиме дека во албанската и во македонската култура комплиментите главно се сметаат за чЗЛ од страна на мажите, додека жените повеќе ги сметаат како чинови кои ги ублажуваат ЧЗЛ.


во најголемиот број случаи првата стратегија е Израз на благооарносй, ни 
сугерира дека во овие две култури многу се води сметка за зачувувањето на позитивното лице на соговорникот. Дури и ако комплиментот се одбива или се избегнува, соговорникот преку учтивоста покажува благодарност, односно дека ја цени добрата намера на говорителот.

Како што можеше да се види и во англиските истражувања, и во албанските и во македонските податоци се потврдува тврдењето на Холмс (Holmes 1988: 447) дека генерално за жените комплиментите претставуваат позитивни афективни говорни чинови, преку кои се зацврстува и се зголемува солидарноста меѓу соговорниците, додека за мажите тие претставуваат ЧЗЛ бидејќи имплицираат завист од страна на говорителот. Во полза на ова тврдење служи и високиот процент на одговори со

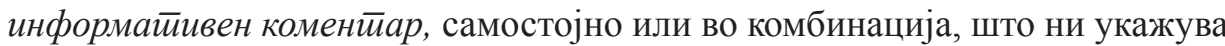
дека и Албанците и Македонците, чинот на давање комплименти го сметаат за ЧЗЛ, и за да не го оштетат своето негативно лице и позитивното лице на говорителот се одлучуваат на оваа стратегија.

Во однос на темите на комплименти, успеавме да утврдиме дека комплиментите за изгледот жените ги сметаат за средство за ублажување, а мажите како ЧЗЛ. Иако првично се сомневавме дека комплиментите за материјалните добра претставуваат ЧЗЛ, анализата на податоците од КПС потврди дека и Албанците и Македонците овој вид комплименти го сметаат како чин кој ги истакнува потребите на позитивното лице на соговорникот, а најголемата сличност се забележува кај честите идиоматизирани изрази со идентично значење во двата јазика: E blefsh mё tё mirë; Поубаво ga cu куйии. Само една разлика во однос на оваа тема е забележана меѓу овие два етникума: Албанците почесто ја минимизираат вредноста на предметот на комплиментот од Македонците, што сугерира дека внимаваат повеќе на почитување на максимата на скромност. Давањето комплименти во однос на способноста на соговорникот претставуваа ЧЗЛ за неговото негативно лице и за да го зачува и воедно да не го оштети позитивното лице на говорителот, соговорникот одлучува учтиво да го избегне дадениот комплимент.

Комплиментите дадени за личноста на соговорникот, овие два етникума ги сметаат за чинови кои го загрозуваат нивното негативно лице, и за да го зачуваат, го оштетуваат позитивното лице на говорителот. Анализата на оваа тема нѐ наведе на една интересна појава: во случаи кога жените сметаат дека еден исказ претставува ЧЗЛ, стануваат поарогантни, и почесто од мажите го оштетуваат позитивното лице на говорителот, одбивајќи го комплиментот преку исказ на несоглласување. ${ }^{7}$ Сепак, ако ја споредиме оваа


и йреgизвикување на искреностиа), може да кажеме дека епомалку агресивна.

\footnotetext{
7 На пример, Не е бам йака. 'Nukështë e vërtetë, mos e dëgjo!' (Не е вистина, не ја слушај).
} 
Ова укажува на фактот дека и кога чувствуваат опасност за лицето, жените, сепак, внимаваат да не предизвикаат прекин на комуникацијата.

Со помош на овие резултати дојдовме до едно многу важно сознание, кое е претходно констатирано од Лејкоф (Lakeoff, 1975): жените, и Македонките и Албанките, се многу пољубезни, односно поучтиви од мажите, бидејќи и кога го прифаќаат, одбиваат или кога го избегнуваат комплиментот, многу

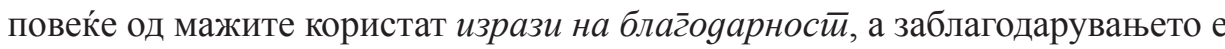
основна стратегија на јазичната учтивост (Нешковска 2014).

\section{Библиографија}

Austin, J. L. (1962). How to do things with words. Oxford: Oxford University Press.

Behnam, B. and Amizadeh, N. (2007). A comparative study of the compliments and compliment responses between English and Persian TV interviews. The Southeast Asian Journal of English Language Studies, 17(1): 65-78.

Bergqvist, T. (2009). Compliment responses among native and non-native English speakers: Evidence of Pragmatic transfer from Swedish into English. Stockholms: Stockholms Universitet.

Brown, P. and Levinson, S. ([1978], 1987). Politeness: Some universals in language usage. Cambridge: Cambridge University Press.

Cedar, P. (2006). Thai and American responses to compliments in English. The Linguistics Journal, 1 (2): 6-28.

Chiang, B. and Pochtrager, F. (1993). A pilot study of compliment responses of Americanborn English speakers and Chinese-born English speakers. Retrieved from: http://files.eric.ed.gov/fulltext/ED356649.pdf

Davis, B. (2008). "Ah excuse me... I like your shirt": An examination of compliment responses across gender by Australians. Griffith Working Papers in Pragmatics and Intercultural Communication, 1(2): 76-87.

Goffman, E. (1967). On face-work: an analysis of ritual elements in social interaction. In E. Goffman (ed.). Interactional Ritual: Essays on face-to-face behaviour, 5-45. New York: Pantheon Books.

Herbert, R. K. (1989). The ethnography of English compliments and compliment responses: A contrastive sketch. In W. Olesky (ed.). Contrastive Pragmatics, 3-35. Amsterdam: John Benjamins.

Herbert, R. (1990). Sex-based differences in compliment behavior. Language in Society, 19: 201-224.

Holmes, J. (1986). Compliments and compliment responses in New Zealand English. Anthropological Linguistics, 28 (4): 485-508.

Holmes, J. (1988). Paying compliments: A sex-preferential politeness strategy. Journal of Pragmatics, 12 (3): 445-465.

Holmes, J. (1995). Women, men, and politeness. London and New York: Longman.

Holmes, J. (2001). An introduction to sociolinguistics: Learning about language. Harlow: Pearson Education Ltd. 
Johnson, D. and Roen, D. H. (1992). Complimenting and involvement in peer reviews: Gender variation. Language in Society, 21: 27-57.

Knapp, M. L., Hopper, R. and Bell, R. A. (1984). Compliments: A descriptive taxonomy. Journal of Communication, 34 (4): 12-31.

Lakeoff, R. (1975). Language and woman's place. New York: Harper and Row.

Leech, G. (1983). Pragmatics. Cambridge: Cambridge University Press.

Livermore, D. (2012). Compliments and cultural intelligence. Retrived from: http://www.management-issues.com/opinion/6548/compliments-and-culturalintelligence/

Lorenzo-Dus, N. (2001). Compliment responses among British and Spanish university students: A contrastive study. Journal of Pragmatics, 33: 107-127.

Manes, J. and Wolfson, N. (1981). The compliment formula. In F. Coulmas (ed.), Conversational routine: Explorations in standardized communication situations and prepatterned speech, 115-132. Hague: Mouton.

Manes, J. (1983). Compliments: A mirror of cultural values. In N. Wolfson and E. Judd (eds.). Sociolinguistics and language acquisition, 96-102. Rowley, MA: Newbury House.

Murphy, L. (2008). Separated by a common language: Observations on British and American English by an American linguist in the UK. Retrieved from:

http://separatedbyacommonlanguage.blogspot.com/2008/06/compliments-nice-andlovely.html

Pomerantz, A. (1978). Compliment responses: notes on the cooperation of multiple constraints. In J. Schenkein (ed.). Studies in the organisation of conversational interaction, 79-112. New York: Academic Press.

Searle, J. R. (1969). Speech acts. Cambridge: Cambridge University Press.

Spielman, R. (1998). 'You're so fat': Exploring Ojibwe discourse. Toronto: University of Toronto Press.

Terkourafi, M. (2004). Testing Brown and Levinson's theory in a corpus of spontaneous conversational data from Cypriot Greek. International Journal of the Sociology of Language, 168: 119-134.

Tsuda, S. (1992). Contrasting attitudes in Compliments: Humility in Japanese and Hyperbole in English. Intercultural Communication Studies II, 1.

Wolfson, N. (1983). An empirically based analysis of complimenting in American English. In N. Wolfson and E. Judd (eds). Sociolinguistics and language acquisition, 82-95. Rowley: Newbury House.

Yakimova, N. (2012). Compliment responses in Bulgarian. Contrastive Linguistics, 37 (4).

Yule, G. (1996). The study of language. Cambridge: Cambridge University Press. 


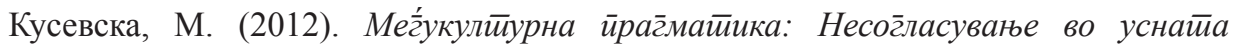
комуникација: анг̄лиски и макеgонски. Скопје: Академски печат.

Нешковска, С. (2014). Заблагодарување. Во: М. Кусевска, 3. Трајкова, С. Нешковска, Ф. Смичковска. Говорни чинови: барање, заблагооgарување, извинување, ӣриг̄оварање во анг̄лискиот̄ и во макеgонскиот̄ јазик, 135-183. Скопје: Академски печат.


и во макеgонскиот̄ јазик. Магистерски труд. Скопје: Универзитет „Св. Кирил и Методиј“". 